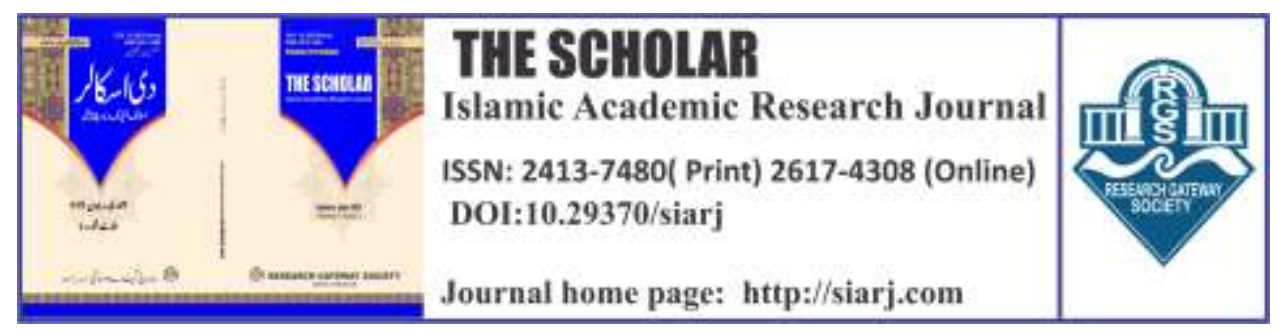

\title{
A CRITICAL STUDY OF THE EARLY YEARS OF ISLAM BY LEOPOLD WEISS (MUHAMMAD ASAD)
}

\author{
1. Mustafeez Alvi \\ Professor, Dean Faculty of Social \\ sciences, National University of Modern \\ languages, Pakistan \\ Email: mustafeez.alvi@numl.edu.pk \\ ORCID ID: \\ https://orcid.org/0000-0002-9047-3391
}

\section{Altaf Ahmed}

Lecturer, Department of Islamic

Studies, National University, Modern

Languages, Islamabad, Pakistan

Email: altaf.ahmed@numl.edu.pk

ORCID ID:

https://orcid.org/0000-0002-8494-2526

To cite this article:

Alvi, Mustafeez, and Altaf Ahmed. "ENGLISH-A CRITICAL STUDY OF THE EARLY YEARS OF ISLAM BY LEOPOLD WEISS (MUHAMMAD ASAD)." The Scholar-Islamic Academic Research Journal 7, No. 2 (December 29, 2021).

To link to this article: https://doi.org/10.29370/siarj/issue13ar5

\begin{tabular}{|c|c|}
\hline Journal & $\begin{array}{l}\text { The Scholar Islamic Academic Research Journal } \\
\text { Vol. 7, No. } 2 \text { | |July -December } 2021 \text { || P.78-100 } \\
\text { Research Gateway Society }\end{array}$ \\
\hline $\begin{array}{l}\text { Publisher } \\
\text { DOI: }\end{array}$ & $\begin{array}{l}\text { Research Gateway Society } \\
\text { 10.29370/siari/issue13ar5 }\end{array}$ \\
\hline URL: & https://doi.org/10.29370/siarj/issue13ar5 \\
\hline License: & Copyright c 2017 NC-SA 4.0 \\
\hline Journal homepage & www.siari.com \\
\hline Published online: & $2021-12-29$ \\
\hline
\end{tabular}
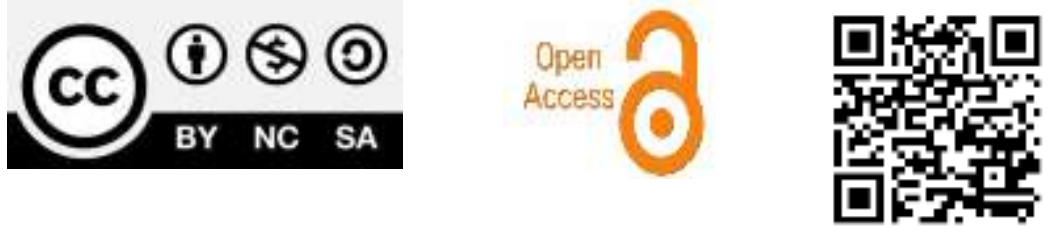
THE SCHOLAR (July-December 2021)

\title{
A CRITICAL STUDY OF THE EARLY YEARS OF ISLAM BY LEOPOLD WEISS (MUHAMMAD ASAD)
}

\author{
Mustafeez Alvi, Altaf Ahmed
}

\begin{abstract}
:
Leopold Weiss alias Muhammad Asad is a European scholar; his family belonged to a Jewish family. Being a journalist, he travelled many parts of the world to discover hidden realties. He went to Arabian countries too where he encountered muslims and saw the Islamic culture and civilization. He got impressed by teachings of Holy Quran particularly the Sura Takthur (سوره تكاثر). As it reveals that the life is short and temporary; all efforts and struggles for worldly benefits will go vanish. After accepting Islam, he devoted himself for the service of Islam. He wrote a lot of research based books about Islam; he is of the view that Islam is not a religion of stories or the religion of past with no application in the present time; rather he is extremely convinced that it is as applicable and valid in today's world as it was in the era of Holy Prophet Muhammad Among his scholarly works, the translation of Sahi ul Bukhari stands unique. His given name to the book is the early years of Islam. He intended to translate it into English in 40 installments; however, he could complete only 5 installments due to the destruction of the Second World War. In this article, we have tried to discuss his brief personal life and his method of translation with analyses. Relevant examples have been presented to make it more comprehensible.
\end{abstract}

KEYWORDS: Muhammad Asad, the early years of Islam, five installments, Islamic culture and civilization. 


\section{MUHAMMAD ASAD PERSONALITY, BIOGRAPHY, WORKS:}

Muhammad Asad has emerged as one of the towering personalities among muslim intellectuals of the twentieth century. His personality and thoughts are increasingly being subjected to detailed studies in the East and the West alike. European calls him "the most influential European Muslim of the $29^{\text {th }}$ century.

His actual name was Leopold Weiss; He was born in July 1900 in the city of lviv (Lemberg), now In Ukraine, ${ }^{1}$ and then part of the Austrian Empire. His family held strong religious views and they were rabbis; he too got religious education to qualify for the position of rabbi. He has strong command over German, French and Polish language.

He joined the Australian Army to fight in the First World War. He then joined University of Vienna to pursue philosophy and history. He could not find spiritual test there and left the institution. In his youth, he was an agnostic and as Jewish religion could not attract him.

After attending the Frankfurter Zietung ${ }^{2}$ as a journalist, he visited Palestine, Egypt, Syria, Iran and Afghanistan. ${ }^{3}$

\section{EMBRACING OF ISLAM:}

Although His understanding of Islam increased by a vast reading and travels, but he could not accept Islam due to his agnostic nature. Still there were many doubts in his mind. But on one day in September 1926, he got

\footnotetext{
${ }^{1}$ Lviv is one of the biggest cities of Ukraine making it the seventh-largest city in the country overall, the number of residents is 717,510 (2021 est.) it is also known for its cultural activities and considered as the main cultural centers of Ukraine.

${ }^{2}$ one of the prestigious newspapers of Germany and Europe

${ }^{3}$ Muhammad Asad, Road to mecca, Islamic book services, New Delhi, 2004 , P1-3
} 
all his answers; and accepted Islam. Actually, he was travelling in Berlin Subway and he saw people well-dressed and well-fed but people were unhappy internally and their inner peace was missing. When he returned home, he say Holy Quran on table, he opened it; the sura was Takathur

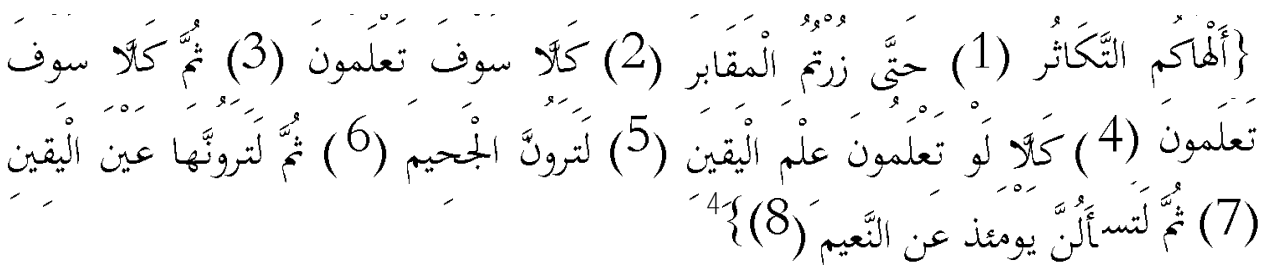

"You are obsessed by greed for more and more until you go down to your Graves. Nay, but you will come to know! and once again: Nay, but they will come to know ne if you but know! Nay, if you but knew it with the knowledge of certainty, you would indeed see the hell you are in. In time, indeed, you shall see it with the eye of certainty: and on that day you will be asked what you have done with the boon of life."

He says: "For a moment I was speechless. I think that the book shook in my hands. Then I handed it to Elsa. "Read this. It is not an answer to what we saw in the Subway"? He added: "It was an answer so decisive that all doubt was suddenly at an end. I knew now, Beyond any doubt, that it was a God- inspired book I was holding in my hand: for although it had been placed before man over thirteen centuries ago, it clearly anticipated something that could have become true only in this complicated, mechanized , phantom-ridden age of ours. ${ }^{5}$

${ }_{5}^{4}[8-1$ - التكاثز 1 ]

${ }^{5}$ M. Ikram Chaghatai , Muhammad Asad Europe's gift to Islam, , sang-emeel Publications, Lahore,2014, vol 1 p 132-134 


\section{ASAD MIGRATES TO THE MUSLIM WORLD:}

As he accepted Islam in 1926, migrated to the Muslim word. There were many reasons of this decision, but the most fundamental one was that he regarded Islam not as a religion in the conventional, or Western sense but considered Islam as a code of life and a way of life for all times.

For him Islam was a balanced religion with all sorts of guidance available for human kinds ranging from individuals to societies, from domestic to international, from spirituality to worldly life. He contends: "Islam appears to me like a perfect work of architecture. All its parts are harmoniously conceived to complement and support each other; nothing is superfluous and nothing lacking; and the result is a structure of absolute balance and solid composure".

His interest in Islam and its followers persisted throughout his life and deeply colored his treatment of all issues touching the Muslims-religious, juristic and political-and he had highly persuasive arguments for his views. When he returned to the Middle East following his conversion, Asad spent almost six year in Arabia, where he was received warmly, almost Daily, by the legendary King 'Abd al- Aziz ibn Saud (d.1373/1953), the founder of modern Saudi Arabia. He spent considerable time in the holy cities of Mekka and Madina where he studied Arabic, the Quran, the hadith, or the traditions of the prophet and Islamic history. He firmly believed that Islah is one of the greatest driving force that can be utilized for the betterment of mankind. ${ }^{6}$

\footnotetext{
${ }^{6}$ IBID P134-135
} 
INVITATION OF IQBAL TO HIM TO STAY IN INDIA:

Asad left Arabia in 1932 to study cultures of India, Eastern Turkestan, China and Indonesia. There he met the celebrated poet philosopher Muhammad Iqbal (d.1357/1938), the towering Muslim thinker of the modern era and the spiritual progenitor of Pakistan. Iqbal persuaded Asad to change his plans and stay on in India "to help elucidate the intellectual premises of the future Islamic state which was then hardly more than a dream in Iqbal's visionary mind".

Asad soon won Iqbal admiration and wide public acclaim among educated circles with the publication of a perceptive monograph on the challenges facing modern Muslims. But his freedom was curtailed where the Second World War broke out in 1939. Ironically, though he had refused to accept a passport from Nazi Germany after it had annexed Australia in 1938 and insisted on retaining his Australian citizenship, the British Raj imprisoned him on the second day of the war as an "enemy alien" and did not release him till its end in 1945. He was the only Western Muslim among the three thousand-odd Europeans rounded up for internment in India, the large majority of whom were sympathizers of Nazism or fascism; some have thought that the British authorities' harsh behaviour to Asad was due to their irritation with the European who always sided with the Indian Muslim community. ${ }^{7}$

\section{IN THE SERVICE OF THE EMERGING MUSLIM STATE OF PAKISTAN:}

He moved to Pakistan after its creation in 1947, and was charged by its government with setting up a department of Islamic Reconstruction whose

\footnotetext{
${ }^{7}$ Ibid p 135-136
} 


\section{A Critical Study of the Early Years of Islam by Leopold Weiss}

(Muhammad Asad)

task was to formulate the ideological foundation for a new state. Later he was transferred to the Pakistan foreign Ministry to head its Middle East division, where he endeavored to strengthen Pakistan's ties to other Muslims countries. He capped his diplomatic career by serving as Pakistan's Minister plenipotentiary to the United Nations. He resigned this position in 1952 to write his autobiography, a work of stunning, ingenuity and unrivalled literary effect.

\section{ASAD PASSES AWAY:}

After writing this book, he left New York in 1955 for other places and finally settled in Spain. He did not ceases to write. At eighty, after an endeavor which lasted seventeen years, he realised his life's dream for which he felt all his life till then was an apprenticeship: a translation and exegesis, or tafsir of the Quran in English. He continued to serve Islam till his death in Spain in February 1992. ${ }^{8}$

With his death passed a journalist, traveler, social critic, linguist, thinker, reformer, diplomat, political theorist, translator and a scholar dedicated to the service of God and humankind and to leading the good life.

\section{WRITTEN WORK OF MUHAMMAD ASAD:}

We shall present his writings in a chronological order.

1-Jerusalem in 1923: the impressions of a young European (1923)

2-The spirit of Islam (1934) this chapter is taken from Islam at the crossroads: the open road of Islam

3-The concept of Religion in the west and in Islam (1934)

\footnotetext{
${ }^{8}$ Ibid 136
} 


\section{A Critical Study of the Early Years of Islam by Leopold Weiss}

(Muhammad Asad)

4-The spirit of the west (1934) this chapter is taken from Islam at the crossroads

5-Sahi Bukhari translation (1935), three editions in 1938, 1981

6-Towards a resurrection of Thought (1937)

7-What Arfat? (1946)

8-The outline of a problem (1946)

9-Is Religion a Thing of the Past (October, 1946)

10-The law of ours (November, 1946)

11-Construction or destruction( February, 1947)

12-That business of imitation( April, 1947)

13-What do we mean by Pakistan? (May 1947)

14-Towards an Islamic constitution (July, 1947)

15-Calling all Muslims (September, 1947) ( a collection of 7 radio broadcasts delivered by him.

16-Arafat- quarterly Journal of Islamic reconstruction ( March, 1948)

17-Islamic reconstruction (March, 1948)

18-Islamic constitution making (March, 1948)

19-The encounter of Islam and the west (1959)( this chapter is taken from this law and ours)

120-Islam and the spirit of our times (1960) (this chapter is taken from this law and ours)

21-The principles of State and Government in Islam (1961), 1980

22-Islam and politics (1963)

23-Jerusalem: the open city (1970) this chapter is taken from this law and ours)

24-The meaning and significance of the Hijrah (1979) (this chapter is taken from this law and ours) 


\section{A Critical Study of the Early Years of Islam by Leopold Weiss}

(Muhammad Asad)

25-The message of Qur'an (1980)

26-A vision to Jerusalem (1982)( this chapter is taken from this law and ours)

27-Jerusalem: a city for all people (1982)

28-A Tribe that kept its name (1985)

THE EARLY YEARS OF ISLAM (TRANSLATION OF SAHIH AL- BUKHARI):

The book First Published in 1938 by Arafat Publications, Lahore and then Reprinted in 1981, 1993 by Dar al-Andalus Limited, Gibraltar.

The new edition was published in 2013 By Islamic Book Trust 607

Mutiara Majestic Jalan Othman 46000 Petaling Jaya Selangor, Malaysia.

The book contains five chapters: the first chapter is on HOW THE

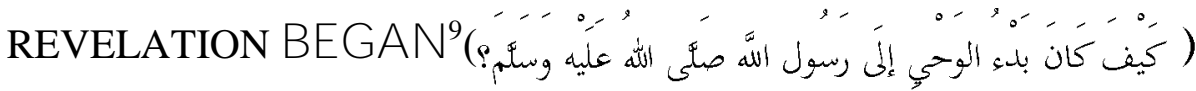

The second chapter is on THE MERITS OF THE

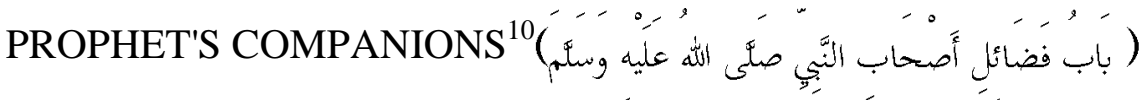

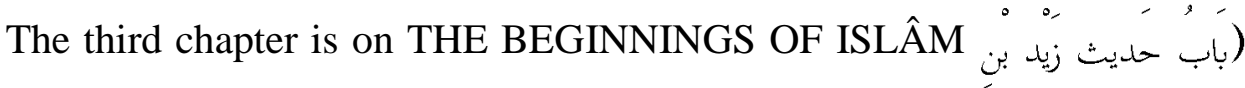

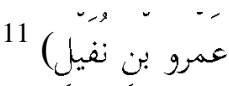

The fourth chapter is on THE BOOK OF CAMPAIGNS: 12 كتاب المغازى

The fifth chapter is on THE BOOK OF FAITH

\footnotetext{
${ }^{9}$ Muhammad bin Ismail, Sahih Al-Bukhari, Publisher: Dar Touq Al-Najat (Illustrated on the authority by adding Muhammad Fouad Abdul-Baqi's numbering numbering) Edition: First, 1422 AH, vol 1 p 6

${ }^{10}$ Sahih Al-Bukhari, Vol 2 p5

${ }^{11}$ Sahih al-Bukhari(40/5)

${ }^{12}$ Sahih al-Bukhari(71/5)
} 


\section{A Critical Study of the Early Years of Islam by Leopold Weiss}

(Muhammad Asad)

He wrote two prefaces of the book. In the first PREFACE, he explains that his book comprises the historical chapters of the most important compilation of Traditions, the Kitab al-Jami ar-Sahi. The five instalments of which the present volume consists will be followed in the course of time, God willing, by thirty-five more instalments containing my translation of, and commentary on, the whole of the Sahih al-Bukhari.

He mentions the reason of taking a huge responsibility of translating Sahih into English that he was sitting in the mosques of Madina, he thought: "What we most urgently need today is a new understanding and a direct appreciation of the true teachings of Islam. In order to achieve this we must once again make real the voice of the Prophet of Islam-real, as if he were speaking directly to us and for us: and it is in the hadith that his voice can be most clearly heard." 14

After that, he defines the The term hadith (pl. ahadith) that it is a narrative or a report in general meanings but it in Islamic teachings it means the records of the sayings and doings of the Prophet Muhammad ${ }^{15}$

Moreover, he highlights how Hadith was preserved; he contends that the memories of arabs were extremely strong. So many companions memorized a huge number of Hadith. Additionally, there were some companions who used to write ahadith. For example, Hazrat Abd Ullah Bin Amr. In the beginning of $3^{\text {rd }}$ century of Hijra, hadith turned to be a developed science ${ }^{16}$. Besides, he puts forward how a hadith is accepted or rejected; a thorough investigation of the reliability of the authorities-or the chain of authorities applied to the Traditions. Different accounts bearing

${ }^{13}$ Sahih al-Bukhari(10/1)

${ }^{14}$ (Asad, Sahih Al- Bukhari the early years of Islam 2013) p 5

${ }^{15}$ (Asad, Sahih Al- Bukhari the early years of Islam 2013) p 5

${ }^{16}$ (Asad, Sahih Al- Bukhari the early years of Islam 2013) p 5 


\section{A Critical Study of the Early Years of Islam by Leopold Weiss} (Muhammad Asad)

on one and the same incident or saying were critically compared, and every chain of narrators (called isnad) subjected to very intense scrutiny. In order that a Tradition be recognized as "sound" (sahih), all facts about the lives of its narrators, commencing with the Prophet's Companion or Companions who first reported it, must be known and historically established, including the fact of an unbroken contiguity in the line of narrators, and a positive proof that every one of them was in personal contact with his authority, i.e., the person who communicated to him the hadith in question. Every one of the narrators must be known to be truthful, pious, just and possessing a faultless memory-so much as that any substantiated challenge (ta'n) on any of these points automatically removes the narrator concerned from the rank of trustworthy authorities (thiqat). And, finally, if two or more persons who otherwise could be regarded as reliable narrate intrinsically conflicting Traditions on the same subject, they lose their position of unquestioned authority, with the result that no Tradition reported by them can by itself (ie, without corroboration by another chain of narrators) be classified as sahih. ${ }^{17}$

It is obligatory to follow Sunnah; Muhammad Asad presents different arguments of necessity of Sunnah. Its need and importance has been mention in the Holy Quran. Furthermore, the Sunnah is applicable and functional today as it was during the life of Holy Prophet.

$\mathrm{He}$ is of opinion that a genuine revival of Islam is impossible without an intensive inquiry into its original spirit. We must build further and higher on the foundations supplied by past generations of scholars and thinkers. We cannot accept the idea that the teachings of Islam could ever be

\footnotetext{
${ }^{17}$ (Asad, Sahih Al- Bukhari the early years of Islam 2013) p 6
} 
The Scholar Islamic Academic Research Journal

Vol. 7, No. 2 || July-December 2021 || P. 78-100

https://doi.org/10.29370/siarj/issue13ar5

exhausted in all their depth; and no word of anyone below the Prophet can ever be considered to be final: all of us who labour at a better understanding of the Word of God and the Example of His Prophet are but travellers aiming at new discoveries in the domain of the spirit. ${ }^{18}$

\section{HIS METHOD OF TRANSLATION AND EXPLANATION:}

1. His method of translation is that he has tried to render its meaning as literally as possible. W hatever he has said himself it has been put into the explanatory notes, and whenever an addition was unavoidable in the text itself for the sake of clarity, he has used brackets to indicate the additions.

For example, for the Hadith in merits of Abu Bakr Arabic text is given.

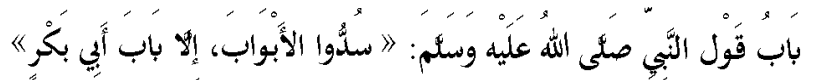

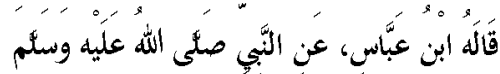

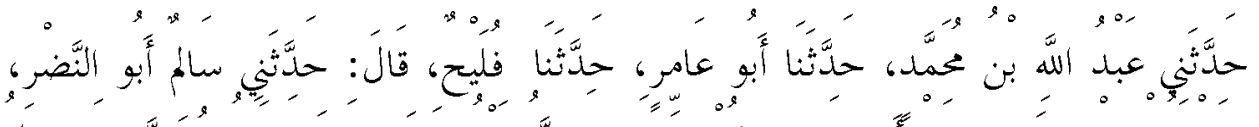

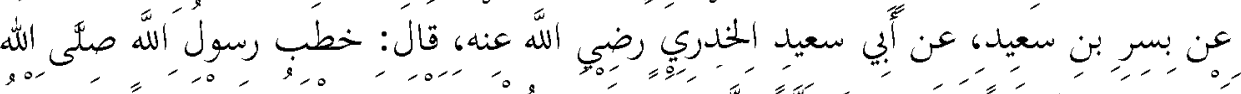

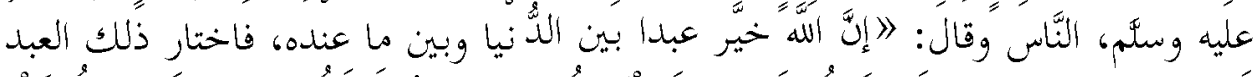

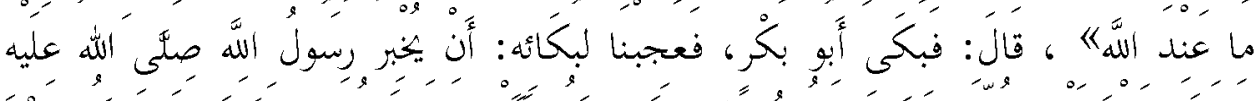

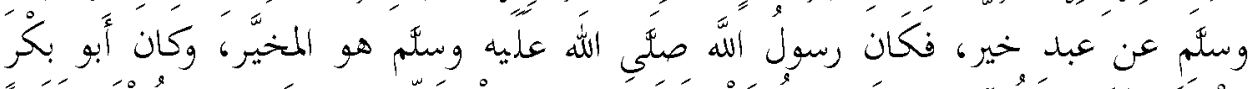

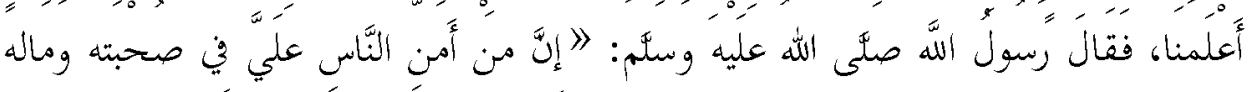

${ }^{18}$ (Asad, Sahih Al- Bukhari the early years of Islam 2013) p 7 
The Scholar Islamic Academic Research Journal

Vol. 7, No. 2 || July-December 2021 || P. 78-100

https://doi.org/10.29370/siarj/issue13ar5

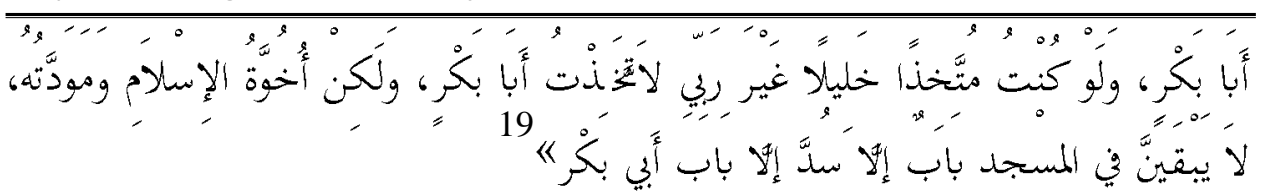

After mentioning Arabic text, he translates beside thé text as folloẃs:

THE SAYING OF THE PROPHET, CLOSE ALL DOORS SAVE THE DOOR OF ABU BAKR:

Ibn 'Abbás related this [Tradition] on the authority of the Prophet.'

Abd Allah ibn Muhammad related to me: Abu 'Amir related to us: Fulayh related to us, saying: Salim abu'n-Nadr related to us, on the authority of Busr ibn Sa'id, on the authority of Abû Sa'id al-Khudri, who said:

THE Apostle of God addressed the people and said: Behold, God gave one of His servants the choice between this world and that which is with Him; and the servant chose that which is with God.-Thereupon Abû Bakr wept; and we wondered at his weeping over the announcement of the Apostle of God concerning one of God's servants who had been given the choice. But it was the Apostle of God himself who had been given the choice, and Abu Bakr knew it better than we. Then the Apostle of God said: Behold, of all people, the most generous to ward me with regard to his companionship and his property was Abû Bakr. And were I to chose anyone but my Sustainer to be my dearest friend, indeed I would chose Abu Bakr; but [for him I cherish] Islâmic bro therliness and love. There shall be left open no door in the mosque-save Abu Bakr's door ${ }^{20}$

2. Each Tradition has been divided, by means of different sizes of type, into two parts: the documentary evidence of

${ }^{19}$ Sahih al-Bukhari(4/5)

${ }^{20}$ (Asad, Sahih Al- Bukhari the early years of Islam 2013) p22 
transmission (isnäd) and the textual substance (matn). AlBukhári's explanatory remarks (tarajim al-abwab) which precede some of the sections are printed in italics. The letter I before some of the isnäds shows that the Tradition to which it belongs is a ta'liq ("suspended" isnád) on account of a missing link in the chain of narrators. The letter $\mathrm{h}$ indicates a tahwil ("transfer") to another line of transmitters. Such as for below Hadith:

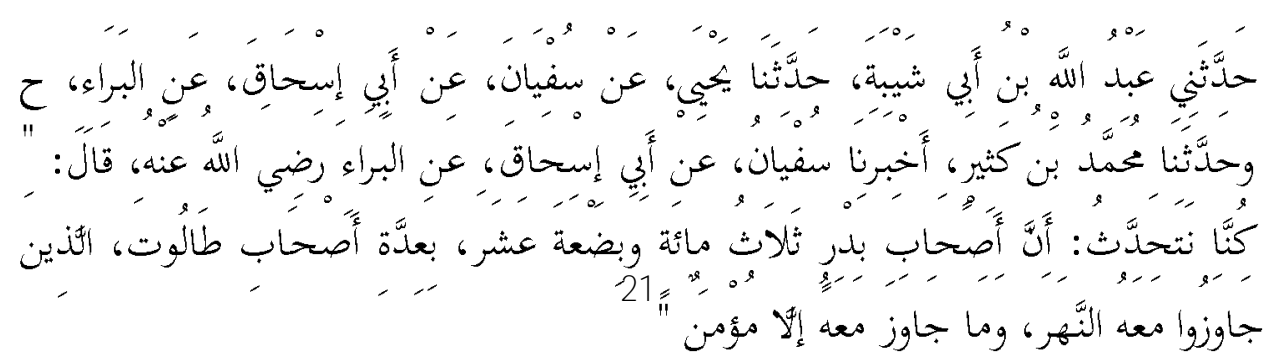

Muhammad Asad translates and mentions the letter $\mathrm{H}$ for indication as:

Abd Allah ibn Abi Shaybah related to me: Yahya related to us, on the authority of Sufyân, on the authority of Abu Ishaq, on the authority of alBara':

(h) And Muhammad ibn Kathir related to us: Sufyân informed us, on the authority of Abu Ishâq, on the authority of al-Bara', who said: (This chain of narrators)

We used to mention among ourselves $\mathrm{W}$ that the Companions of Badr were hree hundred ten and odd [men]-like the number of Saul's companions who crossed he river [Jordan] with him; and none but he faithful crossed [the river] with him. ${ }^{22}$ (This is the translation of text)

So in above Hadith is visible and it's here to show the transfer in the chain.

\footnotetext{
${ }^{21}$ Sahih al-Bukhari(74/5)

${ }^{22}$ (Asad, Sahih Al- Bukhari the early years of Islam 2013) p 267
} 
The Scholar Islamic Academic Research Journal

Vol. 7, No. 2 || July-December 2021 || P. 78-100

https://doi.org/10.29370/siarj/issue13ar5

He answers of a question that why he maintained Isnad in the book while only Matan is sufficient to understand a Hadith. He replies that: "the isnád is an essential part of every hadith-as essential as is the skeleton in the body of every higher animal, including man: for it is with the isnäd that the authenticity of a Tradition stands or falls. Without an isnad, a Tradition is no more than a hearsay report, to be blindly accepted or capriciously rejected; with the isnad before him, on the other hand, the reader is able to see for himself with what meticulous attention to detail and authenticity every şahih Tradition has been recorded: and thus his acceptance of the Tradition becomes endowed with consciousness and ceases to be blind." ${ }^{23}$

3. In addition to this, there is the Arabic text side by side with the translation in the book. He justifies it by saying that it helps readers to grasp and understand the text in a better way. He says: "But some European scholars have pointed out to me that this unnecessarily increases the volume of the work and, consequently, the cost of production; and that the student could well avail himself of any of the existing copies of the Sahih whenever he feels the necessity of independent criticism. I cannot admit this objection as valid. The old style inwhich this and other compilations of Tra ditions are printed makes it, in many cases, exceedingly difficult to separate the frequent interpolations of the transmitters from the textual substance (the matn) of the Tradition, and sometimes even

\footnotetext{
${ }^{23}$ (Asad, Sahih Al- Bukhari the early years of Islam 2013) p 7
} 
leads to a confusion of utterances of different persons with the narrator's statement of facts contained in the matn. ${ }^{24}$

4. He tries to describe original names of companions who later on became famous with a title or another name. for instance, in the book of campaigns he described the original name of Miqdad while translating below Hadith

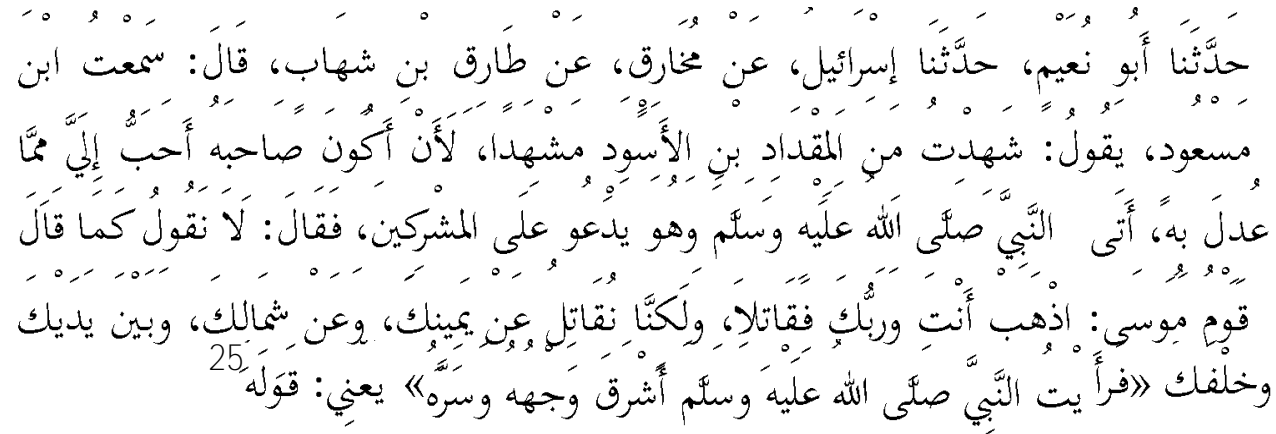

Translation is:

Abu Nu'aym related to us: Isrà'll related to us, on the authority of Mukháriq. on the authority of Tariq ibn Shihab, who said:

I HEARD Ibn Mas'ud say: I heard an utterance by al-Miqdad Ibn al Aswad'. and surely I would give anything for hating made it myself.' $\mathrm{He}$ came to the Prophet while the latter was urging [his followers] against the idolaters'; and [al-Miqdad] said: "we shall not speak as the people of Moses spake, Go thou and thy Lord, and fight ye tuo! Nay, we shall fight on thy right and on thy left, before thee and behind thee!" And I saw the Prophet's face light up with joy on hearing these words.

In footnotes, Asad says: "Miqdad's real patronymic was Ibn 'Amr, but he was called Ibn al-Aswad after his foster father,

\footnotetext{
${ }^{24}$ (Asad, Sahih Al- Bukhari the early years of Islam 2013) p 7

${ }^{25}$ Sahih al-Bukhari(73/5)
} 
al-Aswad ibn 'Abd Yagüth az-Zuhri. He early embraced Islám, but was unable openly to migrate to Madinah with the Prophet. So he remained outwardly a partisan of the pagan Quraysh, until he succeeded to join the Muslims. An opportunity was provided by a military expedition, of which Miqdad was a member, sent by the Quraysh against the Muslims in Shawwal, 1 A.H. They encountered a Muslim raiding party under 'Ubaydah ibn al-Harith; and Miqdåd ibn al-Aswad, accompanied by Utbah ibn Ghazwan, went over to the Muslims. Miqdåd took part in the battle of Badr (in which he was one of the two horsemen which the Muslim army possessed) and in most of the later campaigns, including that of Egypt under 'Amr ibn al-'As. He died in Jurf, near Madinah, in 33 A.H., at the age of seventy". ${ }^{26}$

He mentions the reason of incomplete project in the second preface which was written in 1981. He intended to write translation of whole Sahih al Bukhari in 40 installments but he wrote only 5 installments. He explains that: "the outbreak of the Second World War interrupted the publication. Just as it was about to be resumed, in the summer of 1947, the chaos and the inter-religious holocaust which followed upon the partition of the Indian subcontinent and the establishment of Pakistan (for which I myself had worked and striven since 1933) resulted in a great personal loss-to me as to so many others. Since the end of the war I had been living in the eastern (now Indian) part of the Punjab; and at the outbreak of the partition

\footnotetext{
${ }^{26}$ (Asad, Sahih Al- Bukhari the early years of Islam 2013) p 264
} 
The Scholar Islamic Academic Research Journal

Vol. 7, No. 2 || July-December 2021 || P. 78-100

https://doi.org/10.29370/siarj/issue13ar5

troubles the manuscripts of nearly three-quarters of my annotated translation of the Sahih were barbarically destroyed. With my own eyes I saw a few scattered leaves of those manuscripts floating down the river Ravi in the midst of torn Arabic books-the remnants of my library-and all manner debris; and with those poor, floating pieces of paper vanished beyond recall more than ten years of intensive labour". ${ }^{27}$

Every chapter begins with an introductory note and ends with conclusion except the first chapter HOW THE REVELATION BEGAN as it is without introductory remarks and conclusion.

There are 7 Ahadith in Sahi Ul Bukhari in the chapter named; how the revelation to the Apostle of God Began. However, the translator left the last Hadith and did not translate it. The hadith that has been narrated by Abd Ullah Bin Abbas ${ }^{28}$

The author himself gives a justification by saying: "For technical reasons connected with the photographic reproduction of the first edition of this work, it has become necessary to omit Abû Sufyan's story of his meeting with Emperor Heraclius, as well as Ibn an-Natûr's account of the Emperor's reactions to the message of Islam. Both these accounts are found at the end of the first chapter of the original.

\section{SOME EXAMPLES FROM THE BOOK:}

Now some examples of his book are presented with analyses.

$$
\text { قال البخارى : كتاب الإيمان - متان }
$$

\footnotetext{
${ }^{27}$ (Asad, Sahih Al- Bukhari the early years of Islam 2013) second preface

${ }^{28}$ Sahi ul Bukhari 1/8
} 
The Scholar Islamic Academic Research Journal

Vol. 7, No. 2 || July-December 2021 || P. 78-100

https://doi.org/10.29370/siarj/issue13ar5

-وهو قول وفعل ويزيد وينقص

The Book of Faith

It is word and deed, and it increaseth and decreaseth.

He defines Iman from the linguistic point of view by saying: "iman is derived from the root amn (security); it denotes it from fear or rest of mind. He further defines it's theological meaning: "the faith in God the sincere acceptance of the Islamic shari'ah. The theological definition of faith and question, whether it increases and decreases with the circumstances, is a stationary force in the human soul, has for centuries been the focus of hot controversies among the Muslim thinkers". Among the numberless conflicting opinions we easily can discern four main groups of thought which define Iman as follows:

(1)Belief in heart only. This is according to some exponents of Ash'ari and Maturidi schools of thought, the acknowledgment (taşdiq) of the existence of God and the fact that $\mathrm{He}$ has sent Prophets, of whom Muhammad is the last, to guide mankind according to His Will. Those attributes of God which are not clearly expressed in the Qur'ân and the Sunnah are not an object of Iman and, therefore, the belief in them is open to individual conceptions and not an indispensable condition of salvation. The Jahmiyah school of thought (so called after Jahm ibn Safwan, a theologian who lived towards the end of the Umayyad period) reduces the conception of al bil-qalb to a mere platonic knowledge of God gained by reason.

${ }^{29}$ Sahih al-Bukhari(11/1) 
The Scholar Islamic Academic Research Journal

Vol. 7, No. 2 || July-December 2021 || P. 78-100

https://doi.org/10.29370/siarj/issue13ar5

(2)The saying "There no deity but God, and Muhammad is the Apostle of God." According to Graylån ibn Muslim ad-Dimashqi, Faḍl ar-Raqqashi, and others, the above saying (which for them is equivalent to imán) must be based upon cognition of God in heart, but this cognition does not form part of faith. The Karrimiyah went even further and declared that no such cognition is necessary at all, and that all requirements of imán are fulfilled with the pronunciation of the formula of faith. They obviously confused Iman with Islam in its narrowest, formal sense.

(3)Belief in heart (i'tiqad bil-qalb) in God and all His attributes, as well as in His Prophets and This position is held Revelations, together with an oral profession of this belief (shahadah bil-lisan) ording to them, by Imâm Abu Hanifah, Abü'l-Hasan al-Ash'ari, Bishr al-Marisi, and others. Faith essentially is the acknowledgment (tasdiq) of Truth, and as such it neither can increase nor decrease; it is stationary because of the element of certainty conditional acknowledgment; certainty capable of increasing or decreasing is no certainty at all. Thus, the status of a Faithful (mu'min) is the result of intellectual conviction plus its profession. Good or bad actions may increase or decrease the individual merits of man, but they have no direct influence upon his imán.-The idea that faith is formally independent of actions, whether right or wrong, has been developed to its extreme by the Murji'alt, who declared that belief and its oral profession are sufficient for the attainment salvation, and that the latter can be achieved even if the individual intentionally violates all Divine Commandments. This antinomian view, commonly regarded as heretic by all orthodox Muslim schools of thought, is, together with 
The Scholar Islamic Academic Research Journal

Vol. 7, No. 2 || July-December 2021 || P. 78-100

https://doi.org/10.29370/siarj/issue13ar5

that of the falmiyah mentioned in the first group, the intellectual forerunner of a form of Sofism known as be-shar (ie, not submitting to the law of shari ald which, during the third century after the Hijrah, found culminating point in the ecstatic pantheism of Mansür al-Hallaj. The Murji'ah, as well as the Jahmah. have long since ceased to exert a noticeable influence on Muslim theology.

(4)Belief in heart (inglid bil-qalb) together with its outward profession (sluiháddalt bil-lisin) and the full submission to the commandments of God and His Prophet. This school of thought is represented by most of the Companions of the Prophet, the ashab al hadith, Imams; Malik, Shafi Ahmad ibn Hanbal, al-Awzai. Bukhari, and other learned men of lesser degree. ${ }^{30}$

From this outline of the different theological conceptions of Iman, it appears that the dissensions between the various Muslim schools of thought, so for as this problem is concerned, were actuated by two main points firstly, whether Iman is a purely spiritual matter or is composed of external elements as well, and, secondly, whether it is stationary or changing. As regards the first problem, the overwhelming majority of Muslim theologians, supported by arguments from the Qur'an and the Sunnah, identify themselves with either of the group mentioned under (3) and (4)-that is, with the idea that faith is composed both of spiritual elements (belief, knowledge, etc.) and their outward manifestation (profession of the formula of faith in one case, and profession plus actions in the other). In this respect, the difference between the theologians of the

\footnotetext{
${ }^{30}$ (Asad, Sahih Al- Bukhari the early years of Islam 2013) p 309-310
} 
The Scholar Islamic Academic Research Journal

Vol. 7, No. 2 || July-December 2021 || P. 78-100

https://doi.org/10.29370/siarj/issue13ar5

group (3), eg, Imam Abu Hanifah, and those of the group (4), to whom Imam a Bukhari belongs, consists only in the question whether right actions are an integral part of faith or not. This difference is merely a formal one. Those in group (4) assert that right actions are a part of faith, and indispensable for its completeness, but not for its reality, that is, if a man does not perform right actions he does not cease to be a Faithful (provided his belief and its profession comply with the requirements of the shari ah), but his faith is not perfect, while the theologians of group (3) da not regard right actions as indispensable for the completeness of faith in itself, but, nevertheless, as an important factor man's endeavor to attain full salvation in the Hereafter Thus, according to both schools of thought, right actions (or intentions, as has been made clear in the first Tradition of this work) are decisive factors in the ultimate shaping of man's spiritual destiny.

The too subtle differentiations between actions as "part" or "supplement" of faith belong to the rather antiquated philosophical armoury of NeoPlatonism, and have long since lost all attraction for the modern mind. If we free ourselves from the word-play of the mutakallimún (scholastic theologians)-and it is high time for Muslims to do so-we at once realise that, so far as the question of the composition of faith is concerned, there is little difference between the views enumerated under (3) and (4). ${ }^{31}$

There is, however, a difference in the second part of the problem-that relating to the question whether individual faith can increase and decrease. If we take faith in the sense of mental acknowledgment (tasdiq) with the necessary element of full certainty in it, as, e.g., Imâm Abû Hanifah does,

${ }^{31}$ (Asad, Sahih Al- Bukhari the early years of Islam 2013) p 310 
The Scholar Islamic Academic Research Journal

Vol. 7, No. 2 || July-December 2021 || P. 78-100

https://doi.org/10.29370/siarj/issue13ar5

it is neither clear that it can neither increase nor decrease: it is simply existent or non-existent. But this, it seems, is too narrow a conception of the spiritual phenomenon, "faith," because it limits it to a mere intellectual function. In reality, faith is an extremely complex entity. It is not simply an attitude of mind based on conviction or reasoning alone, but rather an inner movement, a sum total of many spiritual forces and currents whichas in very other movement, spiritual or material-almost permanently vary in their intensity, even if their basis, the intellectual acknowledgment of a truth (that is, belief), remains unchanged.

Modern psychological research has brought forward many interesting evidences of this fact which finds its expression in the Qur'an itself. There we often find the word Huda (guidance) substituted for Iman, and spiritual "guidance" is certainly a very complicated phenomenon. Its coming into existence depends on my widely different factors. To mention only a few time and occasion: the intellectual status of the man concerned; his previous experiences; his physical condition; the influence of his social surroundings, etc. Thus, "guidance" is not simply a one sided Divine function from without the individual but a play of many forces and influences, actions and reactions in one word, a movement like that implied in the term "faith" for which it is substituted. Faith and guidance are essentially dynamic. The dynamic quality inherent in faith makes for the actual difference between faith and belief.

Belief, as defined above, has (as long as it exists) the same degree of intensity, while faith, which is based on belief-but no more identical with the latter than a house is identical with foundations-, is subject to increase and decrease conception (gained, perhaps, by methods of reasoning somewhat different from our present ones) is the foundation on which alBukhari builds his compilation of The Book of Faith. The Arrangement of 
The Scholar Islamic Academic Research Journal

Vol. 7, No. 2 || July-December 2021 || P. 78-100

https://doi.org/10.29370/siarj/issue13ar5

Traditions and the explanations which he has added to different sections of this chapter tend to prove that the Prophet himself conceived Imán as a fluctuating, complex phenomenon; and there is hardly a doubt left that alBukhari has succeeded in his task. The increase and decrease of faith (not to be taken in the sense of quantity, but that of intensity) is psychological fact which cannot be seriously denied; and its practical importance lies in the enhancement of actions as one of the determining factors not only of man's status in the Hereafter, but also of his status Faithful (mu min) in the life of this world. ${ }^{32}$

\section{CONCLUSION:}

This research is an attempt to critically analyze the translation of Sahi Ul Bukhari named "the early years of Islam" by Muhammad Asad. He is a convert Muslim; who dedicated his whole life in presenting a true picture of Islam after he accepted Islam. His translation of Sahi Ul Bukhari is extremely amazing work done by him. We have tried to describe his methods; but there are many areas about the above book that need more research to be conducted.

\section{(9)(1)(0)}

BY NC SA This work is licensed under a Creative Commons

Attribution-NonCommercial-ShareAlike 4.0 International (CC BY-NC-SA 4.0)

32 (Asad, Sahih Al- Bukhari the early years of Islam 2013) p311 